\title{
National security vs criminal law. Perspectives, doubts and concerns on the criminalisation of organised crime in England and Wales.
}

\begin{abstract}
:
This paper will interpret and critically analyse the new offence for organised crime in England and Wales (Section 45 of the Serious Crime Act 2015) from a criminological perspective in light of evidence found in research in the country. It will argue that changes in the law relate to changes in political narratives rather than to variations in the criminal panorama of organised crime. It will discuss these changes within three perspectives, which address various levels of concern: a narrative perspective, which reflects on the overlapping of meanings in the use of the words 'organised crime'; an evolution perspective, which reflects on the origins of the new participation offences with reference to both national and international pressures; a management perspective, which reflects on some of the immediate effects of the new offences of organised crime on the criminal justice system. This paper will conclude that political narratives have indeed influenced criminal policy, while there is no significant change in the phenomenon of organised crime to justify such narratives.
\end{abstract}




\section{Introduction}

When we talk about organised crime, inevitably we encounter the old dilemma of what is organised crime, how we define it and most of all why we need to define it. Such a dilemma is based upon the controversial nature of the concept itself that cannot at once encompass both national manifestations of the phenomena of organised crime and internationally harmonised legal constructs. Definitely, the difference between criminological and sociological dimensions of organised crime and its political conceptualisations is a very problematic issue (Van Dijck, 2007).

Arguably, while sociologists and criminologists researching (manifestations of) organised crime use their own interpretation of the concept according to what the research is about - in terms of empirical data and fieldwork - the political discourse of organised crime often assumes a certain degree of universality in its terminology. However, how the narrative of organised crime is developed at the policy level affects both the perceptions of organised crime phenomena at the social level (Woodiwiss and Hobbs, 2009) and the responses of law enforcement to what become pre-agreed threats then found in acts and regulations (Sergi, 2015a).

When policies change and new offences are introduced in the system, it is mandatory to assess and question the suitability of these offences against the targeted situation(s), as well as it becomes necessary to speculate on the applicability and breadth of these offences once in use. This is the main research question of this paper. This work will primarily discuss the narrative of organised crime in criminal policy in England and Wales at the dawn of the changes brought by the Serious Crime Act 2015 (hereinafter 'the Act'). Among other things, the Act introduces a new offence for participation in criminal activities of organised crime groups. In particular it criminalises both direct and indirect participation in criminal activities of an organised 
crime group. For the purposes of these offences, the Act also defines organised crime groups and their criminal activities.

The aim of this paper is twofold. First, it will interpret and critically analyse the new offence by presenting the new law and its immediate criticisms. Second, the paper will discuss the new offences by focusing on three perspectives, three areas of concerns directly linked to the implementation of the new law, its preliminary criticisms and its links with research on organised crime in the country:

1. The narrative perspective, to reflect on the overlapping of meanings in the use of the words 'organised crime';

2. The evolution perspective, to reflect on the origins of the new participation offences with reference to both national and international pressures;

3. The management perspective, to reflect on some of the immediate effects of the new offences of organised crime on the criminal justice system.

This paper observes that there is no significant change in the phenomenon of organised crime in the country in the past years to substantially justify these changes in policy. We conclude, therefore, that changes in the political discourse are the main drives of the latest legal evolutions.

\section{Organised Crime between international frameworks and national criminal law}

Academic research has tended to focus either on criminal activities linked to organised crime within an "organising crime paradigm" (Van Djick, 2007) or on networks of criminals and types of criminal associations (Paoli and Fijinaut, 2006; Van Djick, 2007; Paoli, 2014; Obokata, 2010). As the conceptualisation and operationalisation of organised crime differs from country to country, so do control 
policies (Paoli and Fijnaut, 2006) and national criminal law often struggles to capture organised crime, as an ontologically composite and elusive phenomenon.

Organised crime is criminalised differently according to different perceptions of the wrongfulness of either criminal activities or criminal networks (Sergi, 2014b; 2015b). To a focus on criminal activities and the organising of crimes correspond offences targeting those criminal activities (usually serious crimes) and offences of conspiracy. Conversely, to a focus on networks and structures of groups corresponds the criminalisation of unlawful associations and/or criminal enterprises (Sergi, 2015b; 2014b; Cancio-Melià, 2008). In both cases the focus on criminal groups is central to criminalisation, either by focusing on an existing agreement among offenders to commit (serious) crimes or by focusing on the existence of a criminal network, more or less hierarchical, planning various criminal activities that together amount to a serious threat to society. In the first case, the emphasis is on the seriousness of the crime, object of the conspiracy agreement; in the second case the focus is on the danger caused by criminal plans to society.

The Legislative Guide to the UN Convention on Organized Crime of 2000 ratified by the UK in 2006 - requires national states to implement either or both conspiracy and unlawful association offences (membership offences) according to their legal traditions as indicated in article 5 of the Convention (UNODC, 2004; 2012). Conspiracy is characterised by "the intentional agreement with one or more other persons to commit a serious crime for a purpose related directly or indirectly to obtaining a financial or other material benefit" (article 5 paragraph 1(a)(i) of the UN Convention) (UNODC, 2004:23). On the contrary, a membership offence requires "general knowledge of the criminal nature of the group or of at least one of its criminal activities or objectives" and "in the case of participating in criminal activities, the mental element of the activity in question would also apply" (article 5, paragraph 
1(a)(ii) of the UN Convention, UNODC, 2004:24). These provisions depend upon the definition of organised crime groups that the UN Convention endorses, which is:

"a structured group of three or more persons, existing for a period of time and acting in concert with the aim of committing one or more serious crimes or offences established in accordance with this Convention, in order to obtain, directly or indirectly, a financial or other material benefit" (art. 2(a)),

where a "structured group" is: "a group that is not randomly formed for the immediate commission of an offence and that does not need to have formally defined roles for its members, continuity of its membership or a developed structure" (art. 2(c)).

A similar framework is also proposed by the Council of Europe Framework Decision of 2008/841/JHA that suggests to take "the necessary measures to ensure that one or both of the following types of conduct related to a criminal organisation are regarded as offences" (art.2): a) conducts related either to active participation within a criminal organisation, with the aim of contributing to the achievements of the organisation's criminal plan; b) conducts related to agreements among two or more persons to commit offences that, if carried out, would fall within the scope of article 1 of the Decision (financial gain or material benefits).

The echo of these provisions when it comes to the laws of England and Wales is clearly distinguishable. Common law countries are often found having a distrusting attitude towards 'guilt by association' offences (Boister, 2012; Walker, 2013) and will accept more easily offences carrying individual - rather than collective - liability. England, until the Serious Crime Act, has not been an exception. Conspiracy was (still is at this stage) the chosen charge in organised crime cases in England and Wales, as confirmed by the Attorney's General Office (2012). Crimes that fall under the umbrella of organised crime are (serious) crimes - which are also, fundamentally, organised (Campbell, 2013) - as indicated both in the Serious Crime Act 2007 Schedule 1 and in 
the Proceeds of Crime Act 2002 Schedule 2: these are crimes such as drug trafficking, arm trafficking, money laundering, terrorism, people trafficking, child exploitation, fraud, corruption, bribery and so on. This mirrors into a policing model focused on the seriousness of various activities of organised crime rather than on the structures of criminal networks (Sergi, 2014a; Sergi, 2015a).

Before the Criminal Law Act 1977 and under common law, a person could have been convicted of both conspiracy and individual offences separately; conspiracy did not merge with the consummated offence (Law Commission, 1976). After 1977 a charge for conspiracy (to do something illegal) is chosen essentially when the prosecutors cannot proceed with the substantive offence ${ }^{1}$ object of an agreement among conspirators (CPS, 2012). Conspiracy is not added to the crime, it is essentially an alternative concurrent charge; this also means that should criminal plans stretch over long periods of time, there will carry several indictments for single offences - each with their own evidence requirements. Indeed, proving one unique conspiracy covering multiple criminal activities seems extremely difficult to achieve in practice (Ormerod and Hooper, 2013). In this perspective, the offence of conspiracy does not capture the complexities of organised crime manifestations where, not only different individuals engage in criminal behaviours, but these behaviours do not always come in the form of agreement and/or in the form of serious crimes.

Both the Home Affairs Committee Report in 1994 and the Home Office White Paper in 2004 in the occasion of the Serious Organised Crime and Police Act 2005 considered changing or substituting the offence of conspiracy in favour of an offence of participation in organised crime activities or membership in organised crime group. The offence of membership in organised crime was rejected on the basis that conspiracy and

\footnotetext{
${ }^{1}$ Practice Direction (Crime: Conspiracy) [1977] 1 W.L.R.537 clarifies that the judge is required to call upon the prosecution to justify the joinder and, if not satisfied, might ask the prosecutor to elect either count of conspiracy or count for substantive offence.
} 
serious crimes seemed adequate charges to prosecute criminal networks engaging in illegal trades (Campbell, 2013; Sergi, 2014a; 2015a). Nevertheless, in the latest Serious and Organised Crime Strategy (Home Office, 2013:37), the Government announced that a proposal for a new offence would "better tackle people who actively support, and benefit from, participating in organised crime, learning from legislation that is already being used elsewhere in the world". Reference was made to the offences proposed by the UN Convention and by the Council of Europe and also to legislation in the United States of America, the RICO Act 1970, and in other countries, such as Italy or Germany. Moreover, the Serious and Organised Crime Strategy approved a national security policing model for organised crime, by presenting the 4-Ps (Prevent, Protect, Pursue, Prepare) as borrowed from counter-terrorism, as viable policing model for the National Crime Agency and other law enforcement authorities when fighting organised crime.

\section{Organised Crime in the Serious Crime Act 2015: Immediate Criticisms.}

The Serious Crime Act 2015 ('the Act') was sponsored by the Home Office and has received Royal Assent on the $3^{\text {rd }}$ of March 2015. The Act includes a number of changes to existing laws (for example the Proceeds of Crime Act, 2002, the Computer Misuse Act 1990, The Policing and Crime Act 2009, the Children and Young Persons Act 1933, the Terrorism Act 2006 etc.). It also includes new provisions for involvement in organised crime groups, for clarifications of the remit of the serious crime prevention orders and for other areas related to sexual offences involving children and restrictions of communications in prisons. In particular, section 45 introduces the offence of participating in activities of organised crime groups. In order to introduce such an 
offence, the Home Office used the terminology 'organised crime group' as generally as possible (section 45 Serious Act 2015 (6)):

"Organised crime group" means a group that-

(a) has as its purpose, or as one of its purposes, the carrying on of criminal activities, and

(b) consists of three or more persons who act, or agree to act, together to further that purpose.

Section 45 adopts the definition of the UN Convention on Transnational Organised Crime and further postulates that:

(1) A person who participates in the criminal activities of an organised crime group commits an offence.

(2) For this purpose, a person participates in the criminal activities of an organised crime group if the person takes part in any activities that the person knows or reasonably suspects

(a) are criminal activities of an organised crime group, or

(b) will help an organised crime group to carry on criminal activities.

Criminal activities (section 45(3)) are activities within subsection $(4)^{2}$ or $(5)^{3}$ carried on with a view to obtaining (directly or indirectly) any gain or benefit. Gain or benefit are financial in nature, as specified in section $45(7)^{4}$.

\footnotetext{
${ }^{2}$ Section 45 (4) Serious Crime Act 2015: Activities are within this subsection if-

(a) they are carried on in England or Wales, and

(b) they constitute an offence in England and Wales punishable on conviction on indictment with imprisonment for a term of 7 years or more.

3 Section 45 (5) Serious Crime Act 2015: Activities are within this subsection if-

(a) they are carried on outside England and Wales,

(b) they constitute an offence under the law in force of the country where they are carried on, and

(c) they would constitute an offence in England and Wales of the kind mentioned in subsection (4)(b) if the activities were carried on in England and Wales.

${ }^{4}$ Section 45 (7) Serious Crime Act 2015:
} 
The Explanatory Notes (Home Office, 2014) to the Bill in 2014, at section 142 state that

The new participation offence in England and Wales is intended to provide a new means by which the NCA, the police and prosecutors can tackle serious organised crime. The new offence can be used to target not only those who head a criminal organisation and who plan, coordinate and manage, but do not always directly participate in the commission of the final criminal acts; but also the other members of the group and associates who participate in activities such as the provision of materials, services, infrastructure and information that contribute to the overall criminal capacity and capability of the organised crime group.

In other words, the offence targets participation in criminal activities - serious and financially driven - of an organised crime group, both directly and indirectly. The spectrum of wrongdoing is quite vast as the offence targets not only those who engage in criminal activities, but also enablers of crime - when they 'reasonably suspect' that their actions will support criminal activities. Enablers of organised crime are solicitors, accountants and other professionals, who now face a maximum penalty of 5 years' imprisonment if found guilty ${ }^{5}$, unless they can use the defence in section $45(8)^{6}$. The Law Society in a note published on their website on the 25 June 2014, noticed how:

The burden of proof is low (reasonable cause to suspect), and it is not clear from the Act how far you would need to go to satisfy yourself that:

For a person to be guilty of an offence under this section it is not necessary-

(a) for the person to know any of the persons who are members of the organised crime group,

(b) for all of the acts or omissions comprising participation in the group's criminal activities to take place in England and Wales (so long as at least one of them does), or

(c) for the gain or benefit referred to in subsection (3) to be financial in nature

${ }^{5}$ Section 45 (9) A person guilty of an offence under this section is liable on conviction on indictment to imprisonment for a term not exceeding 5 years.

${ }^{6}$ Section 45 (8) It is a defence for a person charged with an offence under this section to prove that the person's participation was necessary for a purpose related to the prevention or detection of crime. 
- the service you are providing is not assisting criminal activities down the line somewhere, and

- you had carried out a level of due diligence that to a level that would ensure that you could not be said to have turned a blind eye to criminal activity.

In addition, the Law Society also warned that there are other concerns with "the breadth of the offence; the overlap with existing criminal and money laundering offences; and the additional administrative burdens caused by a potential increase in due diligence measures". Similar concerns on the breadth and the uncertainty of these provisions were raised by the Institute of Chartered Accountants of England and Wales (ICAEW), which went even further in the critique by declaring to Economia (Irvine, 2014) that the new offence:

...would have a number of serious unintended consequences, not only in potentially criminalising many innocent (if naïve) citizens but also reducing access to valuable intelligence currently unavailable to law enforcement authorities and unnecessarily burdening some businesses.

In practice, says the ICAEW, the new offence could make it more difficult for reformed criminals to receive legal and financial advice because professionals will be less comfortable in advising high-risk clients. Both the Law Society and the ICAEW warn about clashes with existing legislation, mostly with reference to the Proceeds of Crime Act 2002 (POCA) and specifically the regime of suspicious activity reports for money laundering (section 330 POCA). As the debate on interpretation of the offence is still at the beginning it is useful to look closer at the new offences also with reference to criminological perspectives.

\section{Participation in Organised Crime Activities: Assumptions and Implications}


As said, section 45 criminalises both direct and indirect participation in organised crime activities. Direct participation occurs when offenders participate in a criminal activity of a group knowing or (reasonably) suspecting that the group's activities are illegal (section 45(2)a). Indirect participation, which targets the enablers of organised crime, requires the intentional engaging in activities with the knowledge or reasonable suspicion that those activities are criminal activities of an organised crime group.

We have already seen how indirect participation has created immediate concerns among professionals. However, in these comments, there is interestingly no reference to the pre-requisite that both types of offences imply for the offences to be committed in the first place, which is the existence of an organised crime group (as defined) committing criminal activities (as defined). At a closer look, therefore, while criminalising a new conduct, which can be committed in two ways, the Act 'squeezes in' conceptualisations of both organised crime groups and their criminal activities. It essentially takes the chance to legally define a concept - organised crime - which however, is still contested and contingent in policy and research. In the Act an organised crime group is rather effortlessly described as a group of three or more people who act together (substantial offence) or agree to act together (conspiracy offence) to commit criminal activities as the main purpose of their association. Moreover, such criminal activities shall be indictable offences in England and Wales punishable with imprisonment for a term of 7 years or more - thus, serious offences - or offences in other countries that would constitute an offence also in England and Wales, to add a cross-border dimension. More importantly, organised crime groups carry out these criminal activities with a view to obtain (directly or indirectly) gain or benefit 'financial in nature' (section $45(7 \mathrm{c})$ ). This means that any serious criminal activities not committed for the purpose of financial gain or profit by a criminal group, would not 
meet the requirements of the offence. The law, therefore, assumes that serious criminal activities, which are committed by organised crime groups, must necessarily aim at financial gain or profit; this might not be the reality of organised crime activities at all. As argued by scholars (Broadhurst et al, 2014; Kleemans and van de Bunt, 2008; Kleemans and de Poot, 2008; Van Duyne, 2000; Makarenko, 2004), the motivation behind 'careers' in organised crimes (especially in trafficking activities and in organised forms of cyber crime) can be the most varied involving quests for power, control, sexual gratification, desire for notoriety and political ideology. Research in the country over the past two-three decades shows how organised crimes can include a variety of offences that can differ in seriousness (Edwards and Levi, 2008; Campbell, 2014). Even though many outcomes of criminal activities can hypothetically fall within financial advantages, gains or profits, the terminology still leads to interpretative confusion.

Digging even deeper, section 45 uses the adjective 'organised' to describe a set of activities committed by a group of three or more persons who act or agree to act together to carry out what are described as 'serious' criminal activities. This unveils another assumption: that if three or more people act, or agree to act, together they automatically fall into some degree of organisational structure. As observed in established literature on the subject, not all crimes perpetrated with a degree of organisation are crimes of organised crime groups, as well as not all criminal associations commit crimes in an organised way (Maltz, 1990; Van Djick, 2007). Indeed, the paradigm of organised crime as 'disorganised crime' (Reuter, 1983; 1985) argues that the illegal provisions of services and goods usually associated with organised crime groups (Paoli, 2002; White, 2006) is actually disorganised in the way the networks work. The disorganised character or criminal networks, their involvement in different activities on more or less occasional basis has been predominant in research in the UK (Wall and Chistyakova, 2015; Hobbs, 2013; Wright, 2006). Moreover, the adjective 'organised' has been proving inadequate when investigating new typologies of 
crimes, especially internet-enabled crimes or cyber-crimes, as well as some forms of drug trafficking or illegal trades in tobacco and alcohol. Some scholars (Broadhurst et at., 2014; Chang, 2012) have also argued for the possibility to have one offender only committing organised crimes in the virtual space. Most crimes have been changing in the past decades to take various forms and to include different types of criminal actors that can range from highly hierarchical gang-style or mafia-style groups to looser networks, from white-collar criminals to online adventurers (Edwards and Jaffrey, 2014; Lavorgna, 2014a; 2014b; Paoli, 2002). A legal definition of organised crime should not rely lightly upon a confused terminology and upon assumptions on motivations and organisation. By doing so, the legislation is over inclusive, while at the same time, it risks unintended consequences. This creates a peculiar situation where on the one hand the legislation is too vague and net widening - it has a too general intent but, on the other hand, it is ineffective towards certain specific phenomena because of the lack of specified targets - it lacks a country-specific intent.

The concerns of professionals and the unpacking of the new offences with their assumptions and implications, raise various concerns on the effectiveness and punctuality of this change in the law. There can be at least three perspectives to approach these concerns: a narrative perspective, an evolution perspective and a management perspective - directly linked the interpretation of the new offences in the Serious Crime Act 2015 and their conceptualisation of organised crime.

\section{The narrative perspective: organised crime between criminal policy and research}

There is a very sharp and visible difference between the narratives of organised crime for policy purposes and the reality of criminal associations, networks and activities as described in research in the country. As a criminological/sociological field 
of research, organised crime has known an unprecedented escalation in interest and outputs of research projects also in England. When looking at early research on organised crime in the UK, it could be argued that the current resolution on establishing and conquering a space for 'organised crime' at the Government level comes as a counter image of those years when researchers and policy makers were less inclined to subscribe to the concept of 'organised crime' when describing the UK (Levi, 2004). On the other side, in the past years organised crime has become a policy label in the UK (Sergi, 2014a; 2015a), in the form of a peculiar national security issue (Campbell, 2014; Woodiwiss and Hobbs, 2009; Home Office, 2010; Home Office, 2013) characterised by both a focus on local criminal networks and strategies to counter serious crimes at a national level (Home Office, 2013; Campbell, 2014; Sergi, 2015a). On a general note, it still seems valid what noticed by Sheptycki (2003): the concept of organised crime in the UK has developed both a denotative and a connotative dimension. At the denotative level, organised crime is the 'illicit economy' and specifically the field for illegal trade and trafficking (Wall and Chistyakova, 2015) that intuitively ought to be 'organised' in crimes such as drugs or trafficking in human beings or money laundering. Organised crime in research in the UK is still described within the denotative dimension. At the connotative level organised crime is, instead, understood in criminal policy as unique monolithic, often alien, threat (Hobbs and Antonopolous, 2013). With the new offence in the Serious Crime Act, the notion of organised crime in England and Wales undergoes another turning point, with the different connotations of the phenomenon and its perceptions even more in conflict with each other.

In a nutshell, in policy, organised crime appears like a compact and multipurpose category; in research, instead, it still preserves its scattered and disorganised character. In fact, in more recent years, research has been ranging from investigations on different criminal activities - grouped under a very controversial label of 'serious (and) organised crime' for policing purposes (Sergi, 2015a) - to investigations on 
networks of offenders and illegal trade (Wall and Chistyakova, 2015). Problems with access to data and measurements of the threats and their costs to society persist. While crimes like drug trafficking or human trafficking have acquired an independent status in research, autonomous from the 'organised crime' rhetoric (Weitzer, 2014), research on criminal networks across the UK has looked at specific places like Liverpool (Lavorgna et al, 2013) or London (Hobbs, 2013) or other hotspots across the country (Edwards and Jeffray, 2014) or at specific crimes, such as money laundering (Leong, 2007) trafficking in artistic objects (Mackenzie, 2011; Dietzler, 2013), counterfeit pharmaceuticals (Lavorgna, 2014a), illegal tobacco (Edwards and Jeffray, 2014), national child trafficking (Brayley et al., 2011) and even counterfeit luxury fashion (Wall and Large, 2010). Evidence from latest research shows how 'it is a scenario in which relatively sophisticated, highly networked organised crime groups run small-scale, highfrequency operations across a diverse set of criminal and legitimate activities' (Edwards and Jeffray, 2014:xi). Furthermore, on-going research carried out by the Police Foundation and Perpetuity Research - to be published in early 2016 - is looking at police intelligence and conducting ethnographic research in two locations in England. The aim of this project is to provide evidence-based data useful to identify what are the most harmful criminal conducts in local areas and how linked they are to organised crime groups. On a general note, most research projects adopt a working definition of organised crime groups based on the level of sophistication of their criminal activities rather than on national security rhetoric, which has been specifically criticised in literature in connection with organised crime (Campbell, 2014). All this considered, the narrative of the new law poses the following concerns: in a country where research suggests that: a) criminal networks/actors involved in illegal trades are not organic or similar, b) do not appear 'formally organised' and c) even when there is a degree of organisation that is not their core connotation, can we still justify a unified concept of 'organised crime' for legal purposes? Or rather, is it the case that connotative 
(conceptual) meanings of organised crime are facilitating the translation and transposition of concepts from foreign experiences to the UK while the denotative (procedural) meanings are getting tangled up in politics as a result?

It can been argued that this represents an example of Hume's Law, an is-ought fallacy according to which the way organised crime should be (compact and multipurpose category of crime for policy purposes) becomes directly - and fallaciously - the way organised crime is (in legal terms) (Sergi, 2015a). From a narrative perspective, there are clear differences between research findings and policy directions when it comes to the terminology of organised crime. If meaning is use and it comes from the interplay of the 'language game' - as argued by Wittgenstein (1968) - then only by using a word or sentence in a way meaningful for others we can demonstrate our understanding of that word or sentence. Language however, is necessarily dynamic and contingent. The meaning of organised crime therefore - when measured against research and snapshots of reality - is functional, contingent and constantly changing through language practices. The words 'organised' and 'crime' are both charged with social and political connotations. Indeed, the meaning of the words 'organised crime' cannot be established a priori but is the result of on-going production and interaction of meanings at various levels, which serves various discourses. In this view, if it does seem neither feasible nor desirable to agree upon a definition, we are left to think that the only proper meaning or sensible interpretation of words or sentences is essentially measured by agreement of use in practice. The success of the terminology of organised crime for policy purposes in the UK and especially in England, from this point of view, is undeniable as it keeps on being reinforced report after report. Indeed, evidence of this success is the language used for example by the media and/or the seemingly unproblematic use of the words organised crime by politicians, lawyers, prosecutors and law enforcement officers. As demonstrated in research (Sergi, 2014a; 2015a; Campbell, 2013), when saying 'organised crime' often what is meant is serious crimes that are 
organised and/or sophisticated gang crimes. This is because research findings in the country do not support a conceptualisation of organised crime as unique threat, as it was the case in other nations (e.g. Italy, and also in the USA historically and in certain instances) with declared formalised criminal groups and criminal identities (e.g. current Italian mafia groups - 'ndrangheta, Camorra, Cosa Nostra - and American La Cosa Nostra). As seen, research in this field in the UK is well anchored to an idea of serious criminal activities committed by loose/flexible networks. If this is the picture, then the law should target serious crimes and/or loose criminal networks. But, instead, as the law criminalises participation in 'organised crime activities' rather than keeping the focus on serious crimes that happen to be loosely organised, England borrows the 'organised crime' conceptualisation from other countries, international policing and even literature and cinema rather than addressing its own forms of organised crime. This well serves political purposes and national security agendas today more comfortable with singlenamed globalised threats (Bigo, 2012). Eventually it comes down to either researchers being wrong - and looking at the threats of organised crime from a partial point of view that diverges from the point of view of policy makers - or policy makers disconnecting the policy target from evidence-based research. In any case, when the single-named conceptualisation of organised crime migrates from policy reports into criminal law the contradictions between policy and research are bound to resurface.

\section{The evolution perspective: the inability of the law to match the narrative of organised crime}

The adaptation of the narrative of organised crime to the needs and requirements of politics and policy-making does not necessarily guarantee a successful implementation of the legislation, like the Serious Crime Act 2015, that uses this narrative. The scepticism of commentators and the criticisms moved against the new 
participation offences - too broad, too general, too demanding - are not only relevant points from practitioners' perspectives, but also reminders that the narrative of organised crime has changed only in the use of the language and not in the reality of the phenomenon as research shows. From an evolution perspective we wonder: why has the law changed at this historical moment if the reality of the phenomenon does not seem to have changed for researchers? And moreover, why have conspiracy offences, deemed to be enough until now, suddenly become insufficient? The answer to such a question remains insufficiently explored.

In other words, on one side, research keeps confirming the extremely complex, extremely varied nature of groups, usually loose and flexible networks of individuals, engaging in a number of specific serious (and) organised crimes (emphasis on the plural). On the other side, however, institutions have been constructing the strategy against organised crime (emphasis on the singular) - as national security threat. This transition, from the plural to the singular, dates back to the 1990s. Whereas British organised crime until the 1990s was a highly local, neighbourhood-based type of gangsterism, after the 1990s professional criminals moved towards an 'entrepreneurial trading culture driven by highly localized interpretations of global markets' (Hobbs, 1995:115). The implications of globalised new market with changing perceptions of glocal perspectives (Hobbs, 1998) characterised organised crime in Britain still as a local phenomenon. The term 'organised crime' in public and political debates was introduced only in 1994 (Home Affairs Committee, 1994), also following a more general tendency of those years to classify organised crime as a hot topic all over the world' (Paoli, 2002:51). Across the 1990s very diverse practices, with drug trafficking in first position, started merging within a newly born criminal category - organised crime - mainly following political and public discourses popular in the USA (Woodiwiss and Hobbs, 2009). By the 2000s organised crime in the UK had become a 'high profile policy concern' (Hobbs and Hobbs, 2012:251) not necessarily backed up 
by reliable data and innovative research (Gregory, 2003). The difficulty to research the phenomenon can be linked to the fact that British organised crime, with a constant nostalgia for 'those traditional forms of organised crime that were so reliant upon...traditional family structures' (Hobbs, 1988:409), was often seen as a set of cooperatives of crime with no leadership and no long-lasting commitments, thus difficult to access and understand (Hobbs, 2013). The effect of flexibility and mobility of groups of criminals eventually meant no real quest for power or control of territories, but rather a developing interest on profits and the ability to engage in different forms of illegal trade.

Not much seems to have changed from an evolutionary perspective since then, if we look at research and studies on the ground and not at politics. By looking at policymaking in contrast with scholarly research it seems obvious to conclude that organised crime as a concept in England and Wales is still torn between singularity and plurality. The former is justifiable because of policy needs - and possibly intelligence data not available to the public - and the latter is instead confirmed by research on illegal markets and trades in certain geographic hotspots. Without resolving this dichotomy, but rather complicating it, the legal 'restyling' proposed by the Home Office in the new provisions of the Serious Crime Act 2015 is certainly an attempt to fill the existing gap between the mandate of intelligence agencies (the NCA fights 'organised crime', intended, however, as a list of serious crimes) and the prosecution/trial phase of cases of organised crime. Moreover, the introduction of the new offence confirms that the concept of organised crime - as singular concept, threat to national security - is now established in policy-making. The national security dimension, which privileges singularity in the terminology of organised crime, on one side echoes international frameworks and other countries' frameworks and, on the other side, carries the advantages associated to national security policing, especially in terms of secrecy of investigations (Walker, 2013; Digo, 2012). A national security conceptualisation of 
organised crime is not compatible with the too generic offence of conspiracy that does not have a label and does not provide, for example, the stigma of 'unlawful associations' (Sergi, 2015b). When wondering why the law has evolved at this specific time, we must notice that, the new offence does not follow any expressed concern from law enforcement in handling these serious/organised crimes through substantial offences (i.e. drug/human trafficking) or general conspiracy (Sergi, 2015a). From an evolution perspective, therefore, we are left to wonder what has prompted such legal change now. We can speculate that the reason for this change now and not earlier (when there was indeed at least a discussion on the suitability of membership offences) or later (if and when research or law enforcement agencies might have called for such a change), is coherent with the full integration of the narrative of organised crime threat in policy-making. That is to say that organised crime now fully enjoys an identity in criminal policy in England and Wales as national security threat and as policy concern as singular criminal category, in spite of what scholars say and despite a policing model still largely targeting activities of organised crime (Sergi, 2015a). Moreover, as reminded in the Impact Assessment of the new offence carried out by the Home Office ${ }^{7}$ 'organised crime is a threat to our national security and causes significant harm to our society. Government has a role in protecting its citizens and ensuring law enforcement agencies have the necessary powers and offences to tackle organised crime'. The impact assessment further explains that conspiracy charges 'make it difficult to pursue people in the wider organised crime group and beyond who 'ask no questions' and support organised crime at arm's length'. The Home Office, therefore, justifies the new law by explaining how crucial it is to target enablers of organised crime, i.e. professionals. This is however, only a portion of the offence and does not justify the overall criminalisation of direct participation in organised crime activities. In any case,

\footnotetext{
${ }^{7}$ Impact Assessment Serious Crime Bill 2014/15 - Home Office Note 02/06/2014
} 
the criminalisation is indeed aligned to international definitions and classifications of organised crime, which have inspired and are completely transposed into the Serious Crime Act 2015. As reminded in the latest Serious and Organised Crime Strategy (Home Office, 2013:37) the Government meant to bring forward proposals to 'better tackle people who actively support, and benefit from, participating in organised crime, learning from legislation that is already being used elsewhere in the world.' International experience has penetrated into the national discourse at the point of becoming national discourse while leaving behind evidence from national studies that still state the fluid, loose, network-based nature of organised crime manifestations. The result is, on one side the confirmation of the national security connotation into criminal law in what is a very broad and not country-specific offence meant to target indirect participation and ending up targeting much more.

\section{The management perspective: practical implications of policy and legal changes}

The offence of direct and indirect participation in organised crime activities targets the pervasiveness of a certain type of criminality - serious and organised - and wishes to protect professional standards as well as to prevent further association among offenders. However, the actual capability to enforce these offences depends as much on the rest of the criminal justice system, from intelligence agencies to the use of the law of evidence, as it does on the interpretation of the offence. The importance of strong intelligence paired with strong evidence for cases against criminal associations has been confirmed by foreign experiences. Both the US RICO Act and the Italian Anti-mafia legislation for example, attach to crimes of illegal enterprise and mafia-type association the possibility to increase the use of interception, surveillance and financial investigations (Goldstock, 1994). Considering that in England and Wales intercepted materials cannot be used in court (Levi and Smith, 2002; Sergi, 2015b), but are solely 
intelligence resources (as for the section 17 of the Regulation of Investigatory Powers Act 2000), the efficacy of offences of organised crime is severely impaired from this point of view. It seems indeed very burdensome to prove the existence of criminal agreements, criminal bonds, gains or profits without the possibility to use criminals' own words. Even though today's means of communication range from instant messaging to VOIP services, the capability to even partially use the information acquired through interceptions still proves to be the most effective weapon in the experience of other countries such as Italy and the US (Campana, 2011; Woodiwiss, 2014). This is an example of how the new law is vague and general - at the point of being over-inclusive - but at the same time is not country-specific; there is indeed little or no point in widening the net of organised crime investigations when the intelligence regulations, as in the case of interceptions, remain the same.

From a management perspective the procedural administration of the new offences in the criminal justice system is also a concern. Both experiences with membership offences in other countries and provisions in counter terrorism - as sibling national security threat - can be used to question the management of the new offences of organised crime. In fact, on one side, as previously said, the new offences of participation are largely borrowed from international provisions and, on the other side they will be used within a national strategy largely modelled upon the counter-terrorism strategy (Home Office, 2013). It is therefore justifiable to wonder if lessons from abroad as well as from national experiences with the law on terrorist organisations can be useful in this case.

If we look at international experiences with offences of organised crime, we can foresee that the effects of these new offences on the criminal justice system will be heavy. Both American and Italian experiences, with RICO illegal enterprise offences and unlawful association/mafia crimes, teach how the whole justice system needs to adjust to offences that, like section 45 of the Serious Crime Act, introduce some form of 
collective/enterprise criminal responsibility, through the criminalisation of organised crime. In fact, even though in participation offences criminal liability is still individual (offenders are singularly charged/convicted/acquitted for their individual participation in organised crime activities), these offences still require, as said, to prove the existence of an organised crime group with a criminal plan to which the offender subscribed and participated. This opens up to the possibility of joint charges and, like in Italy and in the US, to the possibility of 'mega trials'. Moreover, some countries, like Italy, provide special sentencing/prison regimes for (convicted) members of organised crime (to prevent further criminal association) and/or special rules for lifetime management of these offenders outside prison (Sergi, 2015c). Indeed, the new offence will generate a new class of convicted offenders (organised criminals). The label and stigma of organised crime is a powerful one, as seen in both RICO cases and Anti-mafia trials (Jacobs et al, 1996). It can be expected that this label/stigma will develop also in England for convicted offenders, and this is something that the justice system needs to deal with beforehand.

Managing offences of participation in organised crime activities can also prove burdensome from the point of view of prosecution and building of trials. In terms of evidence, for example, it is not clear how well intelligence gathering will work with a distrusting and declared attitude towards 'guilt by association' offences in the English system. As it happened for the offence of membership of a proscribed terrorist organisation $^{8}$, the evidence requirements can become too onerous, the standards too high, which is the reason for very low prosecution and conviction rates for membership in terrorist association (Cole, 2013; Gov.uk, 2014). Difficulties in dealing with an increased workload for investigators, as well as the need for increased resources for prosecutors to build cases under the new offence need to be considered and addressed as

\footnotetext{
${ }^{8}$ Terrorism Act 2000, sections 11-12
} 
concerns. In fact, as the Impact Assessment for this offence has found" 'the number of additional prosecutions following the introduction of the new offence is highly uncertain', which makes it difficult to actually quantify the resources needed. Counterterrorism legislation also teaches that there is a risk of a net-widening effect of the offences. As suggested and feared by the ICAEW and the Law Society, for example, this offence might be used for different purposes than the one intended at the beginning, precisely because it has a general intent, but not a specific remit for the country adopting it. On the other side, there is also a risk that the new offence will serve only a symbolic purpose in the system, as it has been argued in the case of membership for terrorism (Walker, 2013; Walker, 2009).

There is, therefore, the need to understand how to manage this offence, certainly from the point of view of sentencing and punishment (prison regime and lifetime management provisions for example) and from the point of view of intelligence gathering, evidence admissions and applicability of the offences in the first place. The management of these new offences needs specific attention while ad hoc, countryspecific provisions should be preferred to procedures borrowed from elsewhere in the system or from abroad.

\section{Conclusion}

This paper has discussed the new offence of participation in criminal activities of organised crime groups in the Serious Crime Act, proposed by the Home Office and passed on the $3^{\text {rd }}$ of March 2015. While presenting the new offence at section 45 and immediate criticisms, this paper has proposed a criminological critique of the

\footnotetext{
${ }^{9}$ Impact Assessment Home Office Note 02/06/2014
} 
conceptualisation of organised crime in the country between policy discourses and research evidence. In particular, section 45 of the Serious Crime Act defines organised crime groups and their criminal activities; this paper has questioned the suitability of such definitions when matched with the evidence on the phenomenon/a of organised crime as established by criminological research. In interpreting and critically analysing the new offence, this paper has ultimately identified three perspectives for concern in the new law and its conceptualisation of organised crime in the English justice system.

From a narrative perspective there is a mismatch between research findings which conceptualise organised crime as various forms of illicit trades and therefore as a plural phenomenon - and the policy narrative, which addresses organised crime as a national security, single threat with various constituent elements. The new law, instead of resolving this tension, overlaps the two narratives and eventually creates even more confusion in terms of definition of the phenomenon of organised crime in the country.

From an evolution perspective, the changes in the law seem to be driven more by international sources and frameworks than by domestic needs. There seems to have been a transposition of international rhetoric within domestic policy; this is justified neither by law enforcement concerns nor by research findings. Indeed, there is no significant change in the phenomenon of organised crime in the country to actually explain and/or have demanded this latest evolution in the law.

Lastly, from a management point of view, there are procedural concerns related to investigation and prosecution capabilities as well as sentencing/punishment guidelines when it comes to dealing with the new law on a practical level. In consideration of both the narrative and the evolution perspectives, the new offence might generate concerns already seen in foreign jurisdictions - in terms of management of enterprise/membership crimes - and/or from similar national security frameworks such as the counter-terrorism legislation. 
This paper has discussed the existing link between political discourse, criminal policy and criminal law when targeting organised crime and its manifestations in England and Wales. The latest changes in criminal law, while on one side endorsing and confirming the classification organised crime as a national security offence, on the other side, are not justifiable from a practical and evolutionary point of view when looking at the phenomena they target. While the new provisions in the Serious Crime Act surely represent a step forward from a political point of view to 'take organised crime seriously', a thorough assessment of the effects and consequences of the law is needed to avoid waste of resources and confusion in the system.

\section{References}

Bigo, D. (2012), 'Globalization and Security', in Amenta, E., Nash, K., Scott, A., (eds) The Wiley-Blackwell Companion to Political Sociology, Oxford: Blackwell Publishing.

Boister N. (2012), An Introduction to Transnational Criminal Law, Oxford: Oxford University Press.

Brayley, H., Cockbain, E. and Laycock, G. (2011) 'The Value of Crime Scripting: Deconstructing Internal Child Sex Trafficking', Policing: A Journal of Policy and Practice, Vol. 5, Issue 2, Pages 132-143.

Broadhurst, R., Grabosky, P., Alazab, M. and Chon, S. (2014) 'Organizations and Cyber crime: An Analysis of the Nature of Groups engaged in Cyber Crime', International Journal of Cyber Criminology, Vol 8 Issue 1, pp.1-20. 
Cabinet Office (2008) The National Security Strategy of the United Kingdom: Security in an Interdependent World, London: Cabinet Office.

Campana, P., (2011), 'Eavesdropping on the Mob: the functional diversification of Mafia activities across territories', European Journal of Criminology, 8(3), 213-228.

Campbell, L. (2013) Organised Crime and The Law, Oxford: Hart Publishing.

Campbell, L. (2014), 'Organized Crime and National Security: A Dubious Connection?', New Criminal Law Review, 17(2), 220-251.

Cancio Melià M. (2008), 'The wrongfulness of crimes of unlawful association', New Criminal Law Review: An International and Interdisciplinary Journal, 11, p. 563.

Chang, Y. C. (2012), Cybercrime in the Greater China Region: Regulatory Responses and Crime Prevention Across the Taiwan Strait, Cheltenham, UK: Edward Elgar Publishing.

Crown Prosecution Service (CPS) (2012), CPS Guidance on: Joint Enterprise Charging Decisions, Crown Prosecution Service: London.

Department of Justice (DoJ) (2009), Criminal RICO 18 U.S.C. $\$ \S 1961-1968$. A Manual for Federal Prosecutors, 5th Ed., Organized Crime and Racketeering Section, U.S. Department of Justice: Washington DC, available at http://www.justice.gov/usao/eousa/foia_reading_room/usam/title9/rico.pdf [downloaded on 3 February 2015]. 
Dietzler, J. (2013), 'On 'Organized Crime' in the illicit antiquities trade: moving beyond the definitional debate', Trends in Organized Crime, 16(3), 329-342.

Edwards, C. and Jeffray, C. (2014), On Tap: Organised Crime and the Illicit Trade in Tobacco, Alcohol and Pharmaceuticals in the UK, London: Royal United Services Institute

Edwards, A., and Gill, P. (2002), 'The politics of 'transnational organized crime': discourse, reflexivity and the narration of 'threat', The British Journal of Politics \& International Relations, 4(2), 245-270.

Edwards, A., and Levi, M. (2008), 'Researching the organization of serious crimes', Criminology and Criminal Justice, 8(4), 363-388.

Gregory, F. (2003) 'Classify, Report and Measure: the UK Organized Crime Notification Scheme', in: Edwards, A., Gill, P. (Eds.), Transnational Organized Crime. London: Routledge.

Goldstock, R. (1994) Organised Crime In Northern Ireland. A Report For The Secretary Of State And Government Response, The Organised Crime Task Force: Belfast.

Hobbs, D. (1988) Doing the business: entrepreneurship, the working class and detectives in the East End of London, Oxford: Clarendon Press.

Hobbs, D. (1995) Bad business : professional crime in modern Britain, Oxford: Oxford University Press. 
Hobbs, D. (1998). Going down the glocal: the local context of organised crime. The Howard Journal of Criminal Justice, 37(4), 407-422.

Hobbs, D. and Hobbs, S. (2012) 'A bog of Conspiracy: the institutional evolution of organized crime in the UK', in: Allum, F., Gilmour, S. (Eds.), The Routledge Handbook of Transnational Organized Crime, London: Routledge.

Hobbs, D. (2013) Lush Life: Constructing Organized Crime in the UK. Oxford: Oxford University Press.

Hobbs, D., and Antonopoulos, G. A. (2013), 'Endemic to the species': ordering the 'other' via organised crime, Global Crime, 14(1), 27-51.

Home Affairs Committee (1994) Organised crime, London H.M.S.O.

Home Office (2010) Policing in the 21st Century: Reconnecting police and the people, London: The Stationery Office.

Home Office (2013) Serious organised crime strategy, London: The Stationery Office.

Home Office (2014) Explanatory Notes, Serious Crime Bill 2014-15 (HL), 7 November 2014, availabe online at:

\section{http://www.publications.parliament.uk/pa/bills/cbill/20142015/0116/en/15116en.ht}

$\underline{\mathbf{m}}$ [last accessed on 25 February 2015) 
Irvine, J. (2014) 'ICAEW criticises "crooked accountants" Bill', Economia, 16 June 2014, available online at:

http://economia.icaew.com/news/june-2014/icaew-criticises-crooked-accountants-bill [last accessed 25 February 2015]

Jacobs J., Panarella, C. and Worhington, J., (1996), Busting the Mob. United States v. Cosa Nostra, New York: New York University Press.

Kleemans, E., and De Poot, C., (2008) 'Criminal Careers in Organized Crime and Social Opportunity Structure', European Journal of Criminology, 5, 69-98.

Kleemans, E. R., and Van de Bunt, H. G. (2008), 'Organised crime, occupations and opportunity', Global Crime, 9(3), 185-197.

Lavorgna, A. (2014a), 'The online trade in counterfeit pharmaceuticals: New criminal opportunities, trends and challenges, European Journal of Criminology, DOI: 1477370814554722 .

Lavorgna, A. (2014b), 'Internet-mediated drug trafficking: towards a better understanding of new criminal dynamics', Trends in Organized Crime, 17(4), 250-270.

Lavorgna, A., Lombardo, R., and Sergi, A. (2013), 'Organized crime in three regions: comparing the Veneto, Liverpool, and Chicago', Trends in Organized Crime, 16(3), $265-285$.

Law Commission (1976) Conspiracy and Criminal Law Reform Report, London: The Stationery Office. 
Law Society (2014) Government announces serious crime bill, Law Society Website, 25 June 2014, available online at:

http://www.lawsociety.org.uk/news/stories/government-announces-serious-crime-bill/ [last accessed 25 February 2015].

Leong, A.V.M, (2007), 'Chasing dirty money: Domestic and international measures against money laundering', Journal of Money Laundering Control, 10(2), 140-156.

Levi, M. and Smith, A. (2002) A Comparative analysis of Organised Crime Conspiracy Legislation and Practice and their relevance to England and Wales, London: The Stationery Office.

Levi, M. (2004) 'The Making of the United Kingdom's Organised Crime Control Policies', in: Fijnaut, C., Paoli, L. (Eds.), Organised crime in Europe: concepts, patterns, and control policies in the European Union and beyond. The Netherlands: Springer.

Lynch G.E. (1987) 'RICO: The crime of being a criminal', Columbia Law Review, 87, pp. $661-764 ; 87$, pp. 920-984.

Mackenzie, S. (2011), 'The market as criminal and criminals in the market: Reducing opportunities for organised crime in the international antiquities market', in Manacorda S. and Chappell, D. (eds) Crime in the Art and Antiquities World, Springer: New York. 
Makarenko, T. (2004), 'The crime-terror continuum: tracing the interplay between transnational organised crime and terrorism', Global Crime, 6(1), 129-145.

Maltz, M., (1990) Measuring the Effectiveness of Organized Crime Control Efforts, Office of International Criminal Justice, University of Illinois, Chicago.

Obokata, T (2010) Transnational organised crime in international law, Oxford: Hart Publishing.

Ormerod, D. and Hooper, A. (2013) Blackstone's Criminal Practice, Oxford: Oxford University Press.

Paoli, L. (2002) 'The paradoxes of organized crime', Crime, Law and Social Change (37), 51-97.

Paoli, L. (2014) 'Introduction', in Paoli, L. (Ed.), The Oxford Handbook of Organized Crime, Oxford: Oxford University Press.

Paoli, L., and Fijnaut, C. (2006), 'Organised crime and its control policies', European Journal of Crime Criminal Law \& Criminal Justice, 14, 307.

Raville, S. (2009) 'Police create most detailed picture of criminal gangs so far', The Guardian, 13 July 2009.

Reuter, P. (1983) Disorganised Crime. The Economics of the Visible Hand, Cambridge: MIT Press. 
Reuter, P., (1985) The Organization of Illegal Markets: An Economic Analysis, Washington: National Institute of Justice.

Sheptycki, J. (2003) 'Global law enforcement as a protection racket', in Edwards, A. and Gill, P. (eds), Transnational organised crime: perspectives on global security. London: Routledge.

Sergi A. (2014a), 'Structure vs Activity: two models to fight organised crime and their criticisms', Policing: A Journal for Policy and Practice, 8(1), pp. 69-78.

Sergi, A. (2014b), 'Organised crime in criminal law: Conspiracy and membership offences in Italian, English and international frameworks', King's Law Journal, 25(2), 185-200.

Sergi A. (2015a), 'Divergent Mind-sets, Convergent Policies. Policing Models against Organised Crime in Italy and in England within International Frameworks', European Journal of Criminology, Vol. 12 Issue 6, p. 658-680

Sergi A. (2015b) 'Organised Crime in English Criminal Law, Lessons from the United States on conspiracy and enterprise corruption', Journal of Money Laundering Control, Special Issue Organised Crime, Yesterday, Today and Tomorrow, 18(2).

Sergi A. (2015c), 'The Italian Anti-Mafia System between Practice and Symbolism: Evaluating Contemporary Views on the Italian Structure Model against Organized Crime', Policing: A Journal of Policy and Practice, Online First, doi: 10.1093/police/pav028 
UNODC (2004) Legislative Guides for the Implementation of the United Nations Convention Against Transnational Organized Crime and the Protocols Thereto, United Nations Office on Drugs and Crime, Division for Treaty Affairs, New York: United Nations:, available

at http://www.unodc.org/pdf/crime/legislative_guides/Legislative\%20guides_Full\%20vers ion.pdf [last accessed 25 February 2015]

UNODC (2012) Model Legislative Provisions against Organized Crime, United Nations Office on Drugs and Crime, Division for Treaty Affairs, New York: United Nations: available at http://www.unodc.org/documents/organizedcrime/Publications/Model_Legislative_Provisions_UNTOC_Ebook.pdf, [last accessed 25 February 2015]

Van Dijck, M. (2007), 'Discussing definitions of organised crime: word play in academic and political discourse', HUMSEC Journal, 1(1), 65-90.

Van Duyne, P.C., (2000), 'Mobsters are human too: behavioural science and organised crime investigation', Crime, Law and Social Change, 34, 369-390

Van Duyne, P.C., (2011) '(Transnational) Organised Crime, Laundering and the Congregation of the Gullible', 14 March 2011, Tilburg University, Valedictory vol. 14 March 2011, Tillburg University.

Vigna, P.L. (2006) 'Fighting Organized Crime, with Particular Reference to Mafia Crimes in Italy', Journal of International Criminal Justice 4, 522 - 527. 
Walker, C., (2009) 'Prosecuting terrorism: the Old Bailey versus Belmarsh', Amicus Curiae, 79, 21-25.

Walker, C., (2013) 'Terrorists on trial: an open or closed case?', in Cole, D., Fabbrini, F., and Vedaschi, A., (eds) Secrecy, National Security and the Vindication of Constitutional Law, Cheltenham: Edward Elgar.

Wall D and Chistyakova Y. (2015) United Kingdom. In: Savona EU and Riccardi M (eds) From illegal markets to legitimate businesses: the portfolio of organised crime in Europe. Final Report of Project OCP - Organised Crime Portfolio (www. ocportfolio.eu). Trento: Transcrime.

Weitzer, R. (2014) 'New Directions in Research on Human Trafficking', The ANNALS of the American Academy of Political and Social Science, 653(1) pp. 6-24

Wittgenstein, L., (1968) Philosophical Investigations, translated by G.E.M. Ascombe, NewYork: Macmillan Publishing.

Woodiwiss, M. (2012), Organised crime, the mythology of the Mafia, and the American/Anglo Response, in History and Policy, available at http://www.historyandpolicy.org/policy-papers/papers/organised-crime-the-mythologyof-the-mafia-and-the-american-anglo-response [last accessed 25 February 2015).

Woodiwiss, M. (2014), 'The analysis and containment of organized crime in New York City and beyond: an interview with James B. Jacobs', Trends in Organized Crime, 1-8. 
Woodiwiss, M., and Hobbs, D. (2009), 'Organized Evil and the Atlantic Alliance Moral Panics and the Rhetoric of Organized Crime Policing in America and Britain', British Journal of Criminology, 49(1), 106-128.

Wright, A (2006) Organised crime, Cullompton: Willan. 